九州大学学術情報リポジトリ

Kyushu University Institutional Repository

\title{
Potential of Compost with Some Added Supplementary Materials on the Development of Agaricus blazei Murill
}

Horm, Visal

Graduate School of Bioresource and Bioenvironmental Science, Kyushu University

Ohga, Shoj i

Laboratory of Forest Resources Management, Division of Forest Ecosphere Management, Department of Forest and Forest Products Sciences Kyushu Unviversity

https://doi.org/10.5109/12851

出版情報: 九州大学大学院農学研究院紀要. 53 (2)，pp.417-422，2008-10-28. Faculty of Agriculture, Kyushu University

バージョン :

権利関係 : 


\title{
Potential of Compost with Some Added Supplementary Materials on the Development of Agaricus blazei Murill
}

\author{
Visal HORM ${ }^{1}$ and Shoji OHGA* \\ Laboratory of Forest Resource Management, Division of Ecosphere Science and Management \\ Department of Forest and Forest Products Science, Faculty of Agriculture, \\ Kyushu UniversityFukuoka 811-2415 \\ (Received June 27, 2008 and accepted July 16, 2008)
}

\begin{abstract}
Potential of compost on the development of Agaricus blazei Murill was evaluated on various compost concentrations with two kinds of supplementary materials. Sugarcane compost as well as cattle compost added with sawdust and rice bran was influential substrates on mycelial growth and fruit body development. The fast spawn running was realized on cattle compost concentrations, but primordial formation and fruit body development took a short period on sugarcane compost concentrations. All cattle compost concentrations produced the highest biological efficiency, which ranged from $92.29 \%$ to $77.37 \%$, followed by new sugarcane compost concentrations (ranged from $76.78 \%$ to 58.55\%) and old sugarcane compost concentrations (ranged from $71.81 \%$ to $51.95 \%$ ). On cattle compost as well as on sugarcane compost, compost with $50 \%$ and $60 \%$ were the highest potential substrates of the other compost concentrations to produce yield, $\mathrm{BE}$, and mushroom size. The yield was the greatest on $50 \%$ and $60 \%$ cattle compost concentrations, with BE of $92.29 \%$ and $81.04 \%$. New sugarcane compost with $50 \%$ and $60 \%$ concentrations also gave a higher yield and bigger mushroom size, with BE of $72.26 \%$ and $76.78 \%$. Similarly, old sugarcane compost with $50 \%$ and $60 \%$ yielded greatly with BE of $71.81 \%$ and $62.77 \%$, respectively. Out results indicated that compost concentrations was a potential substrate in A. blazei cultivation; nevertheless, increasing the compost ratio did not result in increased mushroom yields with bigger mushroom sizes.
\end{abstract}

\section{INTRODUCTION}

Mushrooms have contributed many advantages to nature such as forest preservation, replanted tree enhancement, recycling woodland debris, and strengthening sustainability of ecosystem. Meanwhile, they are highly nutritious to animals and humans (Stamets, 2005). All edible mushrooms, healthy foods, are high in the $\mathrm{B}$ vitamin and other vitamins including vitamin $\mathrm{C}$, ascorbic acid, ergosterol, a provitamin D, which is high in protein of a good quality (Chang and Hayes, 1978). Furthermore, Mushrooms have been used as medicines and tonics for a long history (Miles and Chang, 1997). Due to their attractively nutritional foods and sources of the development of drugs, various mushrooms have attracted the attention of the biological researches and the artificial cultivations. A. blazei, an edible mushroom originally discovered near a coastal village, Piedade, outside of São Paulo (Bernardshaw et al., 2005), in southern Brazil, is attracting the attention of the scientists in many countries (Lin and Yang, 2006). It, popularly known as mushroom of god (Stamet, 2005), the sun mushroom or Cogumelo do Sol in Brazil, has been exported in Japan since 1965. This mushroom has then become popularly known as Himematsutake or Kawariharatake (Pinheiro et al., 2003), largely produced approximately $100,000-300,000 \mathrm{~kg}$ of the dried bodies every year in Japan (Takaku et al., 2001). This mushroom has been considered to contain the largest quantities of beta glucan among all the mushrooms. Beta glu-

\footnotetext{
Graduate School of Bioresource and Bioenvironmental Science, Kyushu University

* Corresponding author (E-mail: ohga@forest.kyushu-u.ac.jp)
}

can enhances immune systems to fight off predatory environmental and infectious microorganism that can invade and damage virtually every part of the body. Therefore, this mushroom has been commonly used in the treatment and the prevention of cancer, immune deficiency-related diseases, hepatitis, other chronic syndromes, stress-related diseases, diabetes, blood pressure, cholesterol, the danger of bone loss, digestion, and wound or skin problems. Moreover, it posses the beneficial effect on slowing the aging process (Ley, 2001). The A. blazei, basidiomycete, belonging to the Agaricaceae family (Fukuda et al., 2003), is the secondary saprophyte, which prefers growing in actively composting soils. It naturally occurs along forest edges or in pasture rich in debris and decaying woods mixed with animal ordure, requiring high temperature, light, and wet and ventilate environment. Therefore, materials or substrates normally used for cultivation of $A$. blazei are already partially degraded by microorganism, particularly fermented composts. Agricultural wastes, cheap and easily available, namely rice straw, wheat straw, sawdust, rice bran, sugar cane bagasse, and animal manure, are important substrates in mushroom cultivation. Various studies have been conducted to find out the suitable substrates for the cultivation of mushrooms. Meanwhile, cattle compost as well as other agricultural waste composts has been endlessly tested to find out good substrates for the cultivation of $A$. blazei. Therefore, the aim of the study was to determine potential of cattle compost and sugarcane compost with sawdust and supplements on the development of $A$. blazei. 


\section{MATERIALS AND METHODS}

\section{Microorganism}

A strain of Agaricus blazei Murill KS-72 originated from Kyushu University was used in the experiment. It was cultured on Potato Dextrose Agar (PDA) at $24{ }^{\circ} \mathrm{C}$ in darkness. A $5 \mathrm{~mm}$ diameter disc of the third generation of mycelium extension media was transferred to various parameters.

\section{Compost source and substrate preparation}

Three kinds of composts such as cattle compost, new sugarcane compost, and three- year sugarcane compost were used as a basal ingredient for producing spawn as well as substrates. The composts were directly obtained from a local livestock company (Susuki Co. Ltd. Fukuoka, Japan). Data on chemical and physical composition of the compost and supplements used as substrates are presented in Table 1.

Sawdust and rice bran were chosen as supplementary substances to increase mushroom yields and to achieve faster growth. As presented in Table 2, the compost was mixed with sawdust rates of $0 \%, 10 \%, 20 \%, 30 \%, 40 \%$, $50 \%$, and $100 \%$. Each mixture of the substrate was supplemented with rice bran $20 \%$ of the total weight. The moisture of the completed substrate was adjusted to $65 \%$ with tap water. The $100 \mathrm{~g}$ wet substrate was put into the glass Petri dishes, sterilized at $121{ }^{\circ} \mathrm{C}$ for $90 \mathrm{~min}$, and cooled. A $5 \mathrm{~mm}$ in diameter mycelial agar disc was inoculated onto the top of the substrate in glass Petri dishes. The inoculated Petri dishes were incubated at $30{ }^{\circ} \mathrm{C}$ in darkness. Five replications were used for each growing trial. The diameter of mycelium growth was measured in 10 days and spawn running was based on the direct observation. After spawn running was completed, the Petri dishes were cased with 1.5 to $2 \mathrm{~cm}$ of sterilized soil and transferred to the mushroom house for fruit body formation. The temperature of mushroom house was adjusted $24{ }^{\circ} \mathrm{C} \pm 1$, relative humidity was maintained at 90-95\% and $\mathrm{CO}_{2}$ level was less than 1000 ppm. A light intensity of 500 lux was automatically changed from dark to light (12/12h) by way of a fluorescent lamp. The $\mathrm{pH}$ was determined by the HORIBA pH METER F-12 and Ec by CM-60V conductivity meter, respectively. Water holding capacity (WHC) was calculated from the following equation: $\mathrm{W}=$ (wet mass $\times 100 /$ dry mass $)$. Biological Efficiency (BE) is the ratio of gram of fresh mushrooms harvested per pram dry substrate and expressed as a percentage. Mean mushroom size (MS) was determined as follow: total weight of fresh mushrooms harvested/ total number of mushroom harvested. These data were also analyzed by means \pm SD (standard deviation) at $\mathrm{P}<0.05$.

\section{RESULTS AND DISCUSSION}

\section{Effect on vegetative growth}

Ten-day mycelial extension on differently mixed substrates is given in Table 2. Mycelial extension varied in different compost concentrations and compost kinds, except non-compost substrates. The mycelial extension was significantly different in the substrate with different

Table 1. Physical and chemical composition of composts and casing soil

\begin{tabular}{|c|c|c|c|c|c|c|c|c|c|c|}
\hline Ingredients & $\begin{array}{r}\text { Moist } \\
(\%)\end{array}$ & $\mathrm{pH}$ & $\begin{array}{c}\mathrm{Ec} \\
(\mathrm{S} / \mathrm{m})\end{array}$ & $\begin{array}{r}\text { WHC } \\
(\%)\end{array}$ & $\begin{array}{c}\mathrm{H} \\
(\%)\end{array}$ & $\begin{array}{c}\mathrm{C} \\
(\%)\end{array}$ & $\begin{array}{c}\mathrm{N} \\
(\%)\end{array}$ & $\begin{array}{c}\mathrm{K} \\
(\%)\end{array}$ & $\begin{array}{c}\mathrm{P} \\
(\%)\end{array}$ & $\begin{array}{l}\mathrm{K} / \mathrm{P} \\
(\%)\end{array}$ \\
\hline Cattle compost & 65 & 6.26 & $\begin{array}{c}147.5 \\
(\mathrm{Ms} / \mathrm{m})\end{array}$ & 417.6 & 4.97 & 41.84 & 2.34 & 2.38 & 0.72 & 3.30 \\
\hline New sugarcane compost & 32 & 5.48 & 0.286 & 327.9 & 3.43 & 28.75 & 2.93 & 2.05 & 0.40 & 5.08 \\
\hline Old sugarcane compost & 34 & 5.38 & 0.337 & 298.4 & 3.73 & 26.54 & 2.46 & 1.88 & 0.31 & 5.96 \\
\hline Casing soil & 60 & 7.25 & 11.72 & 163.7 & - & - & - & - & - & - \\
\hline
\end{tabular}

WHC-water holding capacity, Ec- Electrical Conductivity, Moist- Moisture

Table 2. Comparison of ten-day mycelial extension of $A$. blazei Murill on various compost concentrations

\begin{tabular}{|c|c|c|c|c|c|c|c|c|}
\hline \multirow[b]{2}{*}{$\begin{array}{c}\text { Compost } \\
(\%)\end{array}$} & \multirow[b]{2}{*}{$\begin{array}{c}\text { Sawdust } \\
(\%)\end{array}$} & \multirow{2}{*}{$\begin{array}{c}\text { Rice } \\
\text { bran } \\
(\%)\end{array}$} & \multicolumn{2}{|c|}{ New sugarcane compost } & \multicolumn{2}{|c|}{ Old sugarcane compost } & \multicolumn{2}{|c|}{ Cattle compost } \\
\hline & & & $\mathrm{pH}$ & $\begin{array}{c}\text { Mycelial } \\
\text { extension }\end{array}$ & $\mathrm{pH}$ & $\begin{array}{c}\text { Mycelial } \\
\text { extension }\end{array}$ & $\mathrm{pH}$ & $\begin{array}{l}\text { Mycelial } \\
\text { extension }\end{array}$ \\
\hline 0 & 100 & 20 & 4.48 & - & 4.48 & - & 4.48 & - \\
\hline 50 & 50 & 20 & 5.06 & $45.5 \pm 6.3$ & 4.35 & $25.8 \pm 3.1$ & 5.13 & $21.0 \pm 1.0$ \\
\hline 60 & 40 & 20 & 5.14 & $41.3 \pm 7.2$ & 4.43 & $26.0 \pm 3.0$ & 5.28 & $22.2 \pm 1.3$ \\
\hline 70 & 30 & 20 & 5.06 & $43.7 \pm 7.5$ & 4.48 & $30.5 \pm 6.6$ & 5.37 & $22.3 \pm 2.2$ \\
\hline 80 & 20 & 20 & 5.04 & $49.2 \pm 6.8$ & 4.52 & $26.6 \pm 7.9$ & 5.52 & $22.8 \pm 0.6$ \\
\hline 90 & 10 & 20 & 4.99 & $55.3 \pm 4.2$ & 4.56 & $27.7 \pm 3.8$ & 5.63 & $32.8 \pm 5.7$ \\
\hline 100 & 0 & 20 & 4.90 & $43.2 \pm 6.8$ & 4.43 & $29.0 \pm 7.0$ & 5.80 & $35.6 \pm 3.4$ \\
\hline
\end{tabular}

Values are the mean \pm SD of mycelial growth measurement (mm) 
composts for ten days of incubation. Mycelia grew fast in new sugarcane compost substrates followed by old sugarcane compost substrates and cattle compost substrates. This was because of high nitrogen contents in sugarcane compost. Substrates containing higher composts promoted better mycelial extension. In cattle compost, the substrates containing $100 \%$ compost were the best for mycelial growth followed by 90\%, 80\%, 70\%, $60 \%$, and $50 \%$, respectively. In new sugarcane compost, composts at 90\% and $80 \%$ were also good at mycelial growth. In old sugarcane compost, the mycelial extension was not significantly different from compost at $100 \%$ to $70 \%$. Therefore, nitrogen was the main factor to lead mycelial extension and increasing compost concentration provided better results in mycelial growth because of high mineral nutrients, moisture, and temperature inside the compost substrates. Naturally, $A$. blazei favors high temperature, so its mycelia can grow vigorously in the increasing concentration of compost substrates.

\section{Effect on spawn running, primordial formation, and fruit body development}

Spawn running was completed when mycelia colonized whole substrates. The result of duration to spawn running, primordial formation, and fruit body development are presented in Table 3 . The most rapid substrate colonization took place in cattle compost concentrations followed by old sugarcane compost substrates and new sugarcane compost substrates. In cattle substrates, higher compost concentrations took a longer colonization period than lower compost concentrations. The fastest colonization occurred with $60 \%, 50 \%$, and $70 \%$ on 32 days and 33 days. It was followed by 35days, 36days, and 37 days with $100 \%, 90 \%$, and 80\%, respectively. In old sugarcane compost, the fastest spawn running took place in 32 days with 100\% compost followed by 36 days, 38 days, 44 days, and 52 days with 80\%, 60\%, 50\%, 70\%, and $90 \%$. Any way, in new sugarcane compost substrates, higher compost concentrations promoted a shorter colonization period. The shortest duration of colonization was 31 days with $100 \%$ compost. It was followed by 32 days with $80 \%$ compost, 38 days with $90 \%$ compost, 47 days with $70 \%$ compost, 51 days with $50 \%$ compost, and 57 days with $60 \%$ compost. Therefore, the result of mycelial extension at 10 days was not correlated with spawn running. Furthermore, the results of primordial formation and fruit body development did not correspond with the results of spawn running. Cattle compost concentration substrates promoted a longer duration of primordial formation and fruit body development, if compared with new sugarcane compost substrates and old sugarcane compost substrates. In cattle compost substrates, there were no significant differences in primordial formation and fruit period among 70\%, $90 \%$, and $100 \%$ compost. The longest duration of primordia formation appeared on 44 days and the first crop obtained on 47 days with 50\% compost concentration (Fig. 1). The shortest period of primordial formation was 27 days with $60 \%$ and $80 \%$ compost and the first crop took 30 days with $60 \%$ compost concentration. However, in new sugarcane compost substrates, the

Table 3. Total day to spawn running, primordial formation, and fruit body development of $A$. blazei

\begin{tabular}{|c|c|c|c|c|c|c|c|c|c|c|c|c|}
\hline \multirow{2}{*}{$\begin{array}{c}\text { Compost } \\
(\%)\end{array}$} & \multicolumn{4}{|c|}{ New sugarcane compost } & \multicolumn{4}{|c|}{ Old sugarcane compost } & \multicolumn{4}{|c|}{ Cattle compost } \\
\hline & SR & $\mathrm{PF}$ & FD & $\mathrm{TDF}$ & SR & $\mathrm{PF}$ & FD & $\mathrm{TDF}$ & SR & $\mathrm{PF}$ & FD & $\mathrm{TDF}$ \\
\hline 0 & - & - & - & - & - & - & - & - & - & - & - & - \\
\hline 50 & 51 & 27 & 30 & 81 & 38 & 25 & 28 & 66 & 33 & 44 & 47 & 80 \\
\hline 60 & 57 & 23 & 27 & 84 & 36 & 24 & 27 & 63 & 32 & 27 & 30 & 62 \\
\hline 70 & 47 & 31 & 35 & 82 & 44 & 26 & 29 & 73 & 33 & 33 & 36 & 69 \\
\hline 80 & 32 & 31 & 35 & 67 & 36 & 22 & 26 & 62 & 37 & 27 & 31 & 68 \\
\hline 90 & 38 & 25 & 29 & 67 & 52 & 24 & 28 & 80 & 36 & 35 & 39 & 75 \\
\hline 100 & 31 & 24 & 27 & 58 & 32 & 22 & 26 & 58 & 35 & 33 & 37 & 72 \\
\hline
\end{tabular}

SR-spawn running, PF- primordial formation, FD- fruit body development, TDF- total day to the first flush

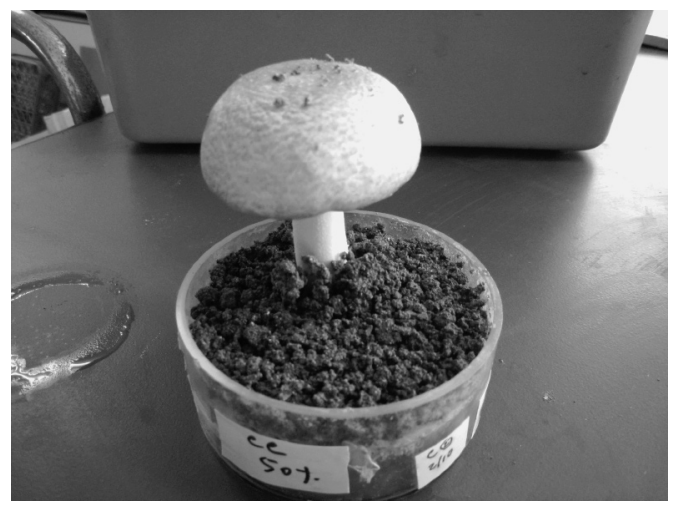

Fig. 1. Fruit body development on $50 \%$ cattle compost.

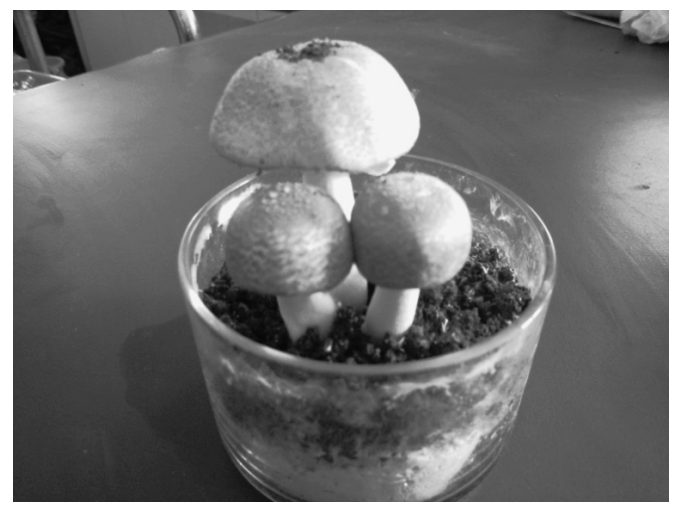

Fig. 2. Fruit body development on $80 \%$ new sugarcane compost. 


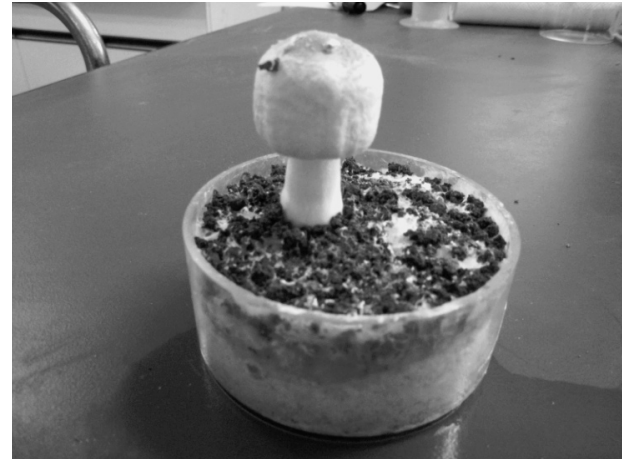

Fig. 3. Fruit body development on $70 \%$ old sugarcane compost.

longest period of primordial formation was on 31 days with $70 \%$ and $80 \%$ compost, which provided fruit body development on 35 days (Fig. 2) and the shortest duration of primordial formation was obtained on 23 days with $60 \%$ compost, which the first crop was 27 days. There were no significant differences in primordial formation and fruit duration among 60\%, 100\%, 90\%, and $50 \%$ compost. Any way, in old sugarcane compost, the longest duration of primordial formation was 26 days with 70\% compost, which promoted fruit body development on 29 days (Fig. 3) and the shortest period of primordial formation was 22 days with $80 \%$ and $100 \%$ compost, which fruit body development took 26 days. There were no considerable differences in primordial initiation and fruit periods among old sugarcane compost concentrations. Satmets (2000) reported that A. blazei on compost took 28-40 days for spawn running, 18-24 days for primordial formation after applying casing soil, and 4-8 days for fruit body development after primordial formation, which total day to the first flush is 50-72 days. Hence, our results were supportive of this finding.

\section{Effect on yields}

The effect of various compost concentrations on the productivity of $A$. blazei was determined by yield, biological efficiency, and size of mushrooms. The most desirable stage to harvest $A$. blazei was when an intact partial veil covered the gills and the pileus (cap) became box-like in form before fully expanding. Average mushroom yields of the two flushes from the five replicates are given in Table 4 (new sugarcane compost), Table 5 (old sugarcane compost), and Table 6 (cattle compost). Results indicated that the first flush provided double or triple products of the second flush because of high nutrient content of substrates at the first flush. This result was not consistent with Stamets (2000). On new sugarcane compost substrates, the highest yield was $29.56 \mathrm{~g}$ on $60 \%$ compost followed by $27.82 \mathrm{~g}$ on $50 \%$ compost, $26.30 \mathrm{~g}$ on $80 \%$ compost, $25.08 \mathrm{~g}$ on $70 \%$ compost, and $24.30 \mathrm{~g}$ on $90 \%$ and $100 \%$ compost with a corresponding biological efficiency of $76.78 \%, 72.26 \%, 62.62 \%, 62.70 \%$,

Table 4. Mushroom yield (fresh wt. (g)/100 g wet substrate), biological efficiency, and mushroom size of $A$. blazei on various concentrations of new sugarcane compost

\begin{tabular}{cccccc}
\hline \multirow{2}{*}{$\begin{array}{c}\text { Compost } \\
(\%)\end{array}$} & First flush & Second flush & $\begin{array}{c}\text { Total fresh } \\
\text { weight }\end{array}$ & $\begin{array}{c}\text { Biological } \\
\text { Efficiency (\%) }\end{array}$ & $\begin{array}{c}\text { Size g/ } \\
\text { mushroom }\end{array}$ \\
\cline { 2 - 3 } & $20.80 \pm 3.53$ & $7.02 \pm 1.65$ & $27.82 \pm 4.70$ & 72.26 & $2.78 \pm 0.47$ \\
50 & $20.24 \pm 4.05$ & $9.32 \pm 1.99$ & $29.56 \pm 4.46$ & 76.78 & $2.96 \pm 0.45$ \\
60 & $16.18 \pm 4.38$ & $8.90 \pm 2.19$ & $25.08 \pm 2.83$ & 62.70 & $2.28 \pm 0.26$ \\
70 & $19.30 \pm 5.02$ & $7.00 \pm 2.44$ & $26.30 \pm 3.70$ & 62.62 & $2.02 \pm 0.28$ \\
90 & $15.20 \pm 6.10$ & $9.06 \pm 3.97$ & $24.30 \pm 7.86$ & 59.27 & $2.03 \pm 0.65$ \\
100 & $16.78 \pm 2.29$ & $7.52 \pm 1.96$ & $24.30 \pm 3.82$ & 58.55 & $2.43 \pm 0.38$ \\
\hline
\end{tabular}

Values are the mean $\pm \mathrm{SD}$

Table 5. Mushroom yield (fresh wt. (g)/100 g wet substrate), biological efficiency, and mushroom size of $A$. blazei on various concentrations of old sugarcane compost

\begin{tabular}{cccccc}
\hline \multirow{2}{*}{$\begin{array}{c}\text { Compost } \\
(\%)\end{array}$} & \multicolumn{2}{c}{ Fresh weight of mushroom by flushes (g) } & \multicolumn{2}{c}{$\begin{array}{c}\text { Biological } \\
\text { Efficiency (\%) }\end{array}$} \\
\cline { 2 - 4 } & First flush & Second flush & Total fresh weight & & \\
\hline 50 & $22.84 \pm 2.40$ & $7.32 \pm 1.21$ & $30.16 \pm 2.90$ & 71.81 & $2.51 \pm 0.24$ \\
60 & $19.06 \pm 4.15$ & $8.56 \pm 3.16$ & $27.62 \pm 6.21$ & 62.77 & $2.30 \pm 0.52$ \\
70 & $17.10 \pm 3.42$ & $7.82 \pm 2.32$ & $25.00 \pm 3.01$ & 58.73 & $2.50 \pm 0.30$ \\
80 & $18.08 \pm 2.83$ & $5.70 \pm 1.42$ & $23.78 \pm 2.53$ & 56.62 & $2.16 \pm 0.23$ \\
90 & $13.58 \pm 1.80$ & $8.50 \pm 1.52$ & $22.08 \pm 3.18$ & 51.95 & $2.21 \pm 0.32$ \\
100 & $13.72 \pm 2.25$ & $9.66 \pm 3.13$ & $23.38 \pm 3.29$ & 53.14 & $2.34 \pm 0.33$ \\
\hline
\end{tabular}

Values are the mean $\pm \mathrm{SD}$ 
Table 6. Mushroom yield (fresh wt. (g)/100 g wet substrate), biological efficiency, and mushroom size of A. blazei on various concentrations of cattle compost

\begin{tabular}{cccccc}
\hline \multirow{2}{*}{$\begin{array}{c}\text { Compost } \\
(\%)\end{array}$} & First flush & Second flush & Total fresh weight & $\begin{array}{c}\text { Bological } \\
\text { Efficiency (\%) }\end{array}$ & $\begin{array}{c}\text { Size g/ } \\
\text { mushroom }\end{array}$ \\
\cline { 2 - 3 } & $22.44 \pm 4.74$ & $9.40 \pm 1.09$ & $31.84 \pm 4.69$ & 92.29 & $3.18 \pm 0.47$ \\
50 & $20.00 \pm 3.71$ & $7.96 \pm 2.08$ & $27.96 \pm 2.99$ & 81.04 & $2.80 \pm 0.30$ \\
60 & $19.30 \pm 1.71$ & $6.64 \pm 1.64$ & $25.90 \pm 1.91$ & 77.37 & $2.59 \pm 0.19$ \\
70 & $19.34 \pm 3.23$ & $7.20 \pm 1.57$ & $26.54 \pm 2.06$ & 79.22 & $2.65 \pm 0.21$ \\
80 & $19.56 \pm 2.35$ & $5.08 \pm 0.67$ & $24.64 \pm 2.63$ & 79.48 & $2.46 \pm 0.26$ \\
90 & $15.52 \pm 3.37$ & $9.18 \pm 1.73$ & $24.70 \pm 2.80$ & 78.41 & $2.47 \pm 0.28$ \\
\hline
\end{tabular}

Values are the mean $\pm \mathrm{SD}$

$59.27 \%$, and $58.55 \%$, respectively. Mushroom size on $50 \%$ compost (2.78g) and 60\% compost (2.96 g) was not significantly different. Furthermore, mushroom side on compost concentration from $70 \%$ to $100 \%$ did not differ significantly, ranging from $2.02 \mathrm{~g}$ to $2.43 \mathrm{~g}$.

On old sugarcane compost substrates, the two flushes crop gave a maximum yield of $30.16 \mathrm{~g}$ on $50 \%$ compost followed by $27.62 \mathrm{~g}$ on $60 \%$ compost with a corresponding biological efficiency of $71.81 \%$ and $62.77 \%$, respectively. The low yield was $22.08 \mathrm{~g}$ on $90 \%$ compost and $23.38 \mathrm{~g}$ on $100 \%$ compost with a corresponding biological efficiency of $51.95 \%$ and $53.14 \%$, whereas moderate yield of $25.00 \mathrm{~g}$ on $70 \%$ compost and $23.78 \mathrm{~g}$ on $80 \%$ compost with a corresponding biological efficiency of $58.73 \%$ and $56.62 \%$, respectively. Size of fruit bodies was slightly larger on low compost concentration substrates, which was $2.51 \mathrm{~g}$ on $50 \%$ compost and $2.50 \mathrm{~g}$ on $70 \%$ compost.

Similarly, on cattle compost substrates, the highest yield ( $31.84 \mathrm{~g}$ ) was obtained from $50 \%$ compost and the moderate yield was $27.96 \mathrm{~g}$ on $60 \%$ compost with a corresponding biological efficiency of $92.29 \%$ and $81.04 \%$, respectively. However, yields did not differ considerably from $70 \%$ compost to $100 \%$ compost, which was $25.90 \mathrm{~g}$ on $70 \%$ compost, $26.54 \mathrm{~g}$ on $80 \%, 24.64 \mathrm{~g}$ on $90 \%$ compost, and $24.70 \mathrm{~g}$ on $100 \%$ compost. In addition, there were not significant differences of their biological efficiency, which was $77.37 \%$ on $70 \%$ compost, $79.22 \%$ on $80 \%$ compost, $79.48 \%$ on $90 \%$ compost, and $78.41 \%$ on $100 \%$ compost. Size of fruit bodies was large on 50\% compost (3.18g) and on 60\% compost (2.80 g), and was not significantly different from 70\% compost to $100 \%$ compost. As a result, various ratios of new sugarcane compost provided better yield and higher biological efficiency than that of old sugarcane compost because new sugarcane compost contained higher nutrient contents than old sugarcane compost. Moreover, various concentrations of cattle compost produced the best yield and the highest biological efficiency if compared with new and old sugarcane compost. It was because the cattle compost contained higher nutrient contents and water holding capacity than sugarcane compost. Meanwhile, the result also revealed that the higher concentration of sugarcane compost as well as cattle compost produced lesser yield and biological efficiency. Thus, more addition of compost to the substrate significantly decreased mushroom yield probably because of a high content of nitrogen and ammonia as growth inhibitor of this fungi in compost. Our result was consistent with the result of Baysal, et al. (2003) and Laborde, et al. (1984). Generally, selection of a variety of substrate materials for the cultivation of mushroom is largely based on low cost but highly obtained yield. Substrates used for cultivation of $A$. blazei in the experiment was agricultural wastes, cheat and easily available. Cattle compost as well as sugarcane compost in particular when added to sawdust and rice bran was able to promote development of A. blazei. In the present study, it is clearly showed that $50 \%$ and $60 \%$ compost concentration added with supplements sawdust and rice bran can produce good yields.

\section{CONCLUSIONS}

The A. blazei, secondary saprophyte, grows in fermented substrates particularly composting soil rich in plant debris. Non-compost substrates were not advantageous for its growth. Compost substrates, sugarcane compost as well as cattle compost, were massive potential for its cultivation. Sugarcane compost substrates led better mycelial extension than cattle compost substrates, but their spawn running took a longer period than cattle compost concentrations. Any way, sugarcane compost substrates produced earlier primordial initiation and fruit body development than cattle compost concentrations; however, they provided lower yield, mushroom size, and biological efficiency than cattle compost substrates. Meanwhile, this study also revealed that new sugarcane compost concentrations gave better results for biological efficiency than old sugarcane compost concentration. Furthermore, on sugarcane compost as well as cattle compost, high compost concentrations did not provide better results for biological efficiency and yield with bigger sized mushrooms; nevertheless, a higher percentage of supplementary materials could stimulate higher yield and biological efficiency.

\section{REFERENCES}

Baysal, E., H. Peker, K. M. Yalinkilic and A. Temiz 2003 Cultivation of oyster mushroom on waste paper with some added sup- 
plementary materials. Bioresour. Technol., 89: 95-97

Bernardshaw, S., E. Johnson and G. Hetland 2005 An extract of the mushroom Agaricus blazei Murill administered orally protect against systemic streptococcus pneumoniae infection in mice. Immunology, 62: 393-398

Chang, T. S. and A. W. Hays (Ed). 1978 The biology and cultivation of edible mushrooms, pp. 401. Academic press, Inc. New York, USA

Fukuda, M., S. Ohno and M. Kato 2003 Genetic variation in cultivated strains of Agaricus blazei. Mycoscience, 44: 431-436

Laborde, J., P. Clauzel, O. Crabos and J. Delmas 1984 Aspects pratiques de la culture de Pleurotus sp. In: Proceeding of the International Symposium on substrate for mushrooms growing and Cultivation of Pleurotus species. Part II. pp. $66-97$

Ley, M. B. 2001 Discovery the beta glucan secret, medicinal mushrooms for immune enhancement: Agaricus blazei Murill, pp. 5-33. BL Publication. Detroit lakes, MN. USA

Ling, H. J. and S. S. Yang 2006 Mycelium and polysaccharide pro- duction of Agaricus blazei Murill by submerged fermentation. Microbiology, Immunology and Infection., 39: 98-108

Mile, G. P. and S. T. Chang 1997 Mushroom biology, concise basic and current developments, pp. 5-8. World Scientific. Convent garden. London

Pinheiro, F., R. R. Faria, V. L. J. Camargo de, T. L. A. Spinardi-Barbisan, F. A. Eira da and F. A. Barbisan 2003 Chemoprevention of preneoplastic liver foci development by dietary mushrooms Agaricus blazei Murill in the rat. Food and Chemical Toxicology, 41: 1543-1550

Stamets, P. 2000 Growing Gourmet and Medicinal Mushrooms, Third edition pp. 208-216. Ten speed press. Berkeley, California. USA

Stamets, P. 2005 Mycellium running, How mushroom can help save the world, pp. 65-119. Ten speed press. Berkeley, California. USA

Takaku, T., Y. Kimura and H. Okuda 2001 Isolation of antitumor compound from Agaricus blazei Murill and its mechanism of action. Nutritional Sci., 131: 1409-1413 